University of Vermont

UVM ScholarWorks

College of Agriculture and Life Sciences Faculty

Publications

College of Agriculture and Life Sciences

2017

\title{
Ecoenzymes as Indicators of Compost to Suppress Rhizoctonia solani
}

Deborah A. Neher

The University of Vermont, dneher@uvm.edu

Lynn Fang

The University of Vermont

Thomas R. Weicht

The University of Vermont

Follow this and additional works at: https://scholarworks.uvm.edu/calsfac

Part of the Agricultural Science Commons, Environmental Microbiology and Microbial Ecology Commons, and the Plant Pathology Commons

\section{Recommended Citation}

Deborah A. Neher, Lynn Fang \& Thomas R. Weicht (2017) Ecoenzymes as Indicators of Compost to Suppress Rhizoctonia Solani, Compost Science \& Utilization 25(4): 251-261.

This Article is brought to you for free and open access by the College of Agriculture and Life Sciences at UVM ScholarWorks. It has been accepted for inclusion in College of Agriculture and Life Sciences Faculty Publications by an authorized administrator of UVM ScholarWorks. For more information, please contact scholarworks@uvm.edu. 
Citation: Deborah A. Neher, Lynn Fang \& Thomas R. Weicht (2017) Ecoenzymes as Indicators of Compost to Suppress Rhizoctonia Solani, Compost Science \& Utilization, 25(4):251-261, DOI: 10.1080/1065657X.2017.1300548

\title{
Ecoenzymes as indicators of compost to suppress Rhizoctonia solani
}

\author{
Deborah A. Neher*1, Lynn Fang ${ }^{1,2}$, Thomas R. Weicht ${ }^{1}$ \\ ${ }^{1}$ Department of Plant and Soil Science, University of Vermont, Burlington, Vermont, USA \\ ${ }^{2}$ Soil \& Compost Consulting \& Education at The Growing Club, Diamond Bar, California, USA \\ Correspondence*: \\ Department of Plant and Soil Science \\ University of Vermont \\ 63 Carrigan Drive \\ Burlington, VT 05405 USA \\ Phone: 802-656-0474 \\ Fax: 802-656-4656 \\ Email: deborah.neher@uvm.edu
}

\section{ACKNOWLEDGEMENTS}

The authors thank commercial composters for providing samples of their product, including Highfields Center for Composting, Grow Compost, Vermont Compost, VT Natural Ag Products, Green Mountain Compost, and Worm Power Vermicompost. The Vermont Agricultural Experiment Station Competitive Hatch Program VT-HO1609 funded the research and Ms. Flore Costume extracted, counted and identified nematodes as an undergraduate research project.

ABSTRACT Reports of disease suppression by compost are inconsistent likely because there are no established standards for feedstock material, maturity age for application and application rate. The overall goal of the study was to evaluate a suite of biological indicators for their ability to predict disease suppression. Indicators included both commercial available methods for compost stability (Solvita ${ }^{\mathrm{TM}}$, respiration) and metrics of soil ecology not yet adopted by the compost industry (e.g., ecoenzymes, nematode community index). Damping-off by Rhizoctonia solani on radish was chosen as a model system given its global importance, competitiveness affected by carbon quality, and lack of disease management options for organic production. Biological indicators were evaluated for their ability to consistently differentiate among curing process, maturity, and feedstock material as a function of disease severity of a seedling bioassay and a compost extract assay to test competition with $R$. solani growth. Compost processed as vermicompost and anaerobic digestate were more suppressive against $R$. solani than windrow or aerated static pile. Mature composts were more suppressive than immature components. Feedstocks containing dairy manure and/or hardwood bark tended to have suppressive qualities. In contrast, poultry manure based components were conducive to disease. Microbial ecozymes active on chitin and cellulose and nematode community indices 
were better predictors of disease suppressiveness than microbial respiration. These indicators are quicker than plant bioassays and could be adopted as tools to certify commercial products.

Keywords: disease suppression, extracellular enzyme assays, indicators, nematode communities, vermicompost

\section{INTRODUCTION}

Finished compost should be stable and mature, two terms that are often used interchangeably, so it can be safely packaged and transported, and not cause adverse effects during its end use (Wichuk and McCartney 2010). Stability is a resistance to decomposition and is usually determined using indices of microbial activity. Commonly recommended of the stability tests is some variation of a compost self-heating test through respirometry (Gómez et al. 2006) or the 8-point color scale Solvita ${ }^{\mathrm{TM}}$ test produced by Woods End Laboratory (Brinton et al. 1995). Solvita ${ }^{\mathrm{TM}}$ is simple and practical but has been criticized for its imprecision and cost. In contrast, maturity infers that the material is ready for a particular use, and, for horticultural purposes, is determined by plant germination and growth assays. Plant bioassays are a gold standard because they empirically determine whether there are any detriments to plant growth or development (Wichuk and McCartney 2010). Effective plant bioassays are standardized by plant cultivar and environmental conditions, but are time-consuming (2-4 weeks) to complete which may be longer than desired. Comparably robust, but quicker (1-2 day) assays would be ideal for quality control and quarantine programs.

Vegetable farming represents 14\% of US agricultural market in 2016 (USDA-ERS 2016) and provides nearly double the return per acre than other agricultural operations in the Northeast (Chan et al. 2011). Total number of vegetable farms is increasing in the Northeast and market projections suggest the vegetable market overall and the organic vegetable market will increase in the coming decade. Additions of composted organic matter are considered beneficial for vegetable cropping systems because they contribute positively to soil quality and provide fertility. The recipe, curing process, and maturity have unique impacts on the soil microbiology (Neher et al. 2013) and influence the ecological succession of soil microbial communities. These impacts on soil biology are $26 \%$ effective in suppressing plant pathogens (Bonanomi et al. 2007; Jack et al. 2011).

Rhizoctonia solani Donk (Kuhn [teleomorph Thanatephorus cucumeris (Frank)] is listed as one of most important pathogens on crop plants that provide the primary sources of human nutrition (Strange and Scott 2005). $R$. solani is an aggressive fungal pathogen with a wide host range, including Solanaceae, Fabaceae, Asteraceae, Brassicaceae, and has a global distribution. When alone with a host, it colonizes the root, monopolizing a resource to the point of competitive exclusion (Klein et al. 2013). It a difficult disease to manage because it is a facultative saprophyte and able to survive as sclerotia under adverse environmental conditions (González García et al. 2006). Few methods are available for managing $R$. solani aside from not planting too deeply, and removing weeds to ensure good air circulation. There is no genetic resistance to $R$. solani (Grosch et al. 2004) and a limited choice of seed varieties that meet the organic certification standards of seed production and pelleting.

Successful and reliable suppression of $R$. solani has been shown in greenhouse trials with vermicompost (Ersahin et al. 2009), and thermophilic composts made from hardwood bark 
(Nelson and Hoitink 1983), organic household waste (Tuitert et al. 1998), viticulture and enological factory residues (Pane et al. 2010), cow manure (Pane et al. 2013), swine manure (Diab et al. 2003), municipal waste (Mathout 1987) and grape marc. However, grape marc compost also showed conduciveness towards $R$. solani (Santos et al. 2008), showing the inconsistency of compost use in disease suppression. Municipal waste compost stored near piles of composted hardwood bark suppressed $R$. solani, while those that were not stored near composted hardwood bark were not suppressive (Kuter et al. 1988). These conflicting findings stress the importance of consistent feedstock chemistry curing process, and maturity in $R$. solani suppression.

Fungi Trichoderma harmatum and Gliocladium virens are known antagonists of Rhizoctonia (Hoitink and Boehm 1999). Composts prepared from hardwood tree barks become colonized by Trichoderma spp. and Gliocladium spp. or other related Hypocreaceae (Hoitink and Boehm 1999; Neher et al. 2013). Wood-based carbon has higher lignin:cellulose ratios than hay or straw-carbon based composts. Pathogens, such as Rhizoctonia solani, are favored in early stages of composting when a concentration of labile carbon is high (Chung et al. 1988). Once labile carbons are depleted, the efficacy of biological control fungi such as Trichoderma hamatum increases (Chung et al. 1988). T. hamatum hyperparasitizes mycelium of Rhizoctonia solani by producing cellulases, glucanases, and chitnases. Given the variety of composts shown to suppress $R$. solani suggests that managing carbon quality and compost maturity will alter relative competition between biocontrol microbes and the pathogen (Nelson and Hoitink 1983; Ersahin et al. 2009).

The objectives of the study were: 1) determine whether process, maturity or feedstock of commercial compost products is a consistent predictor of disease suppression, and 2) identify the most reliable indicators of disease suppression. Indicators evaluated included current industry standards (Thompson et al. 2001) as well as indicators proposed by research laboratories including extracellular enzyme assays (Castaldi et al. 2008), nematode community indices (Neher 2010; Steel et al. 2010), and a compost extract plate competition assay (Alfano et al. 2011). The ultimate goal was to identify a quick and accurate test to predict suppressive potential of compost toward $R$. solani.

\section{MATERIALS AND METHODS}

\section{Model pathogen system}

Local isolates of Rhizoctonia solani Donk (Kuhn [teleomorph Thanatephorus cucumeris]) (Frank) were collected from Vermont grown potatoes and radishes. Infected pieces were excised, grown in water agar, and incubated at room temperature. We chose radish (Raphanus sativus), Ping Pong variety from Johnny's Seeds (Fairfield, Maine USA), for its quick growth and ease of detecting $R$. solani infection at the white root crown. Radish is recommended for germination tests because of its precision and accuracy among compost types compared to other vegetable seeds (Komilis and Tziouvaras 2009). The isolates most virulent on radish were kept in long-term storage on a minimal media of corn meal agar slants (at $5^{\circ} \mathrm{C}$ ), and used to infest soils for greenhouse bioassays. $R$. solani is less likely to lose virulence in culture than Oomycota or bacteria pathogens (personal observation).

Inoculum was cultured in a sterile mix of $96 \mathrm{~g}$ sandy soil, $4 \mathrm{~g}$ corn meal, and $20 \mathrm{ml}$ water. The culture medium was autoclaved for $1 \mathrm{hr}$ over three consecutive days to ensure that any 
endospores of Bacillus were killed. Plugs of $R$. solani growing on potato dextrose agar were transferred to the culture medium, covered with foil, and incubated at room temperature for 23 weeks until the culture medium was overgrown with mycelium.

\section{Compost types}

Composts from a variety of different commercial facilities were chosen based on maturity and pile type (Table 1). Production processes included 1) aerated static piles (ASP) often followed by windrow curing, 2) windrows aerated by a bucket loader or excavator, 3) vermicomposts produced by a 2-step process where materials were first composted past the thermophilic stage, then fed to compost worms (Eisenia fetida) for maturation. Immature and mature compost was just 0 and 3 to 6 months of curing after the thermophilic phase, respectively. Feedstocks were mixed food waste, poultry manure, food waste and poultry manure, dairy manure and silage only, or hardwood bark as the primary carbon substrate. We were not able to achieve a full factorial design, as we relied on what local producers had available in Vermont and New York.

\section{Plant bioassay}

Field soil (Adams and Windsor loamy sands) was steam pasteurized at $70^{\circ} \mathrm{C}$ for four hours to destroy native pathogens, then re-inoculated with its endemic microbial community by adding $4 \mathrm{~L}$ of $10 \mu \mathrm{m}$ filtered soil extract, and sat for three weeks to allow the microbial community to re-establish itself. Half the soil was inoculated with mixed local isolates of $R$. solani (100ml inoculum per liter of soil), and was allowed one week to equilibrate with the soil before compost was incorporated. ASP, windrow and vermicompost were applied respectively at $10 \%, 10 \%$ and $1.25 \%(\mathrm{v} / \mathrm{v})$. These application rates exhibited the greatest disease suppression in preliminary trials (Fang 2015). A negative control of no compost in uninfested soil served as a reference. Treatments were replicated four times. Compost-soil mixtures were allowed to equilibrate for 1 week after which 25 radish seeds were planted into each pot using a customized dibble-stick to ensure a distance of $254 \mathrm{~mm}$ between each seed. Four replicate pots were ascribed to each treatment sample. Plant bioassays were performed in the greenhouse under natural day lengths and watered daily. Radish seedlings were allowed to grow for 2 weeks until the emergence of one true pair of leaves after which each bioassay was harvested. Each seedling hypocotyl was examined under a stereoscope and rated for disease severity on a scale of 1-5. A percentage disease severity was ascribed for each rating, based on the HorsfallBarratt scale (Horsfall and Cowling, 1978). The mean disease severity was computed from the midpoint percentages. Treatment results were expressed as a percent change in disease severity from the negative control.

\section{Indicators of disease suppression}

Each compost sample was homogenized and subsamples were analyzed for a variety of bioindicators: microbial carbon, $\mathrm{CO}_{2}$ respiration, ratio of total carbon to total nitrogen $(\mathrm{C}: \mathrm{N})$, electrical conductivity (EC), $\mathrm{pH}$, plate competition assay, extracellular enzyme activity (hereafter referred to as ecoenzymes), and nematode community indices (Table 2). Compost industry typically relies on measures of respiration, carbon, salinity and $\mathrm{pH}$ as indicators of stability and 
phytotoxicity (Thompson et al. 2001). In addition, we evaluated three additional indicators described briefly below.

Plate competition assay. A half gram of compost was added to $50 \mathrm{ml}$ sterile water and shaken overnight (adapted from Alfano et al. 2011). The next day, 1.5g agar was added to $50 \mathrm{ml}$ deionized water and autoclaved for 30 minutes. It was cooled to $55^{\circ} \mathrm{C}$, mixed in with the compost water extract, swirled gently to mix, and poured into $100 \mathrm{~mm} \times 15 \mathrm{~mm}$ plastic petri plates. The next day, plugs of $R$. solani growing on potato dextrose agar were transferred onto the compost water extract plates, and pure water agar plates were used as a control. Plates were incubated for 24 hours at room temperature. The mycelium radius was then measured to the nearest $1 \mathrm{~mm}$ using a microscope. Three of the longest radii were recorded, and the mean was used as a representative measure to compare suppressive potential among different compost samples. This assay was completed five times in replicate per compost type. All measurements were standardized against the control of mean mycelium radial growth on water agar.

Ecoenzymes. Hydrolase, oxidase, amino-peptidase, and esterase activity was quantified as indicators of microbial functional activity and expressed as nmol h-1 $\mathrm{g}^{-1}$ of dry compost. Hydrolases ( $B G=\beta$-glucosidase and NAG $=\beta-1,4-N$-acetylglucosaminidase) serve as an indicator for hydrolysis of plant and fungal cell walls, respectively. Oxidase (peroxidase and phenol oxidase), L-leucine aminopeptidase (LAP) and phosphatase (PP) activity are indicators for degradation of lignin, proteins, and phosphate, respectively (Moorhead et al. 2013). Sample suspensions were prepared by adding $0.5 \mathrm{~g}$ compost to $100 \mathrm{ml}$ of $50 \mathrm{mM}, \mathrm{pH} 7.0$, sodium bicarbonate buffer and homogenizing for 90 seconds with a Brinkman Polytron. The microplates were organized to assay three samples per plate, with two columns of 8 wells each, for 16 replicates for each sample, along with controls ( $250 \mu$ l buffer alone, $200 \mu$ l buffer with 50 $\mu \mathrm{l}$ reference, and $200 \mu \mathrm{l}$ buffer with $50 \mu \mathrm{l}$ substrate). The reference standard was a $50 \mu \mathrm{M}$ solution. Substrates were prepared as $200 \mu \mathrm{M}$ solutions in nanopure (18.2 megohm) water. Microplates are covered and incubated at $20^{\circ} \mathrm{C}$ for 2 hours. After incubation, they are quantified using a microplate fluorimeter (FLx800, Bio-Tek Instruments) with 360nm excitation and 460nm emission filters.

Oxidative enzyme substrates consisted of 50mM L-DOPA for the phenol oxidase assay and $50 \mathrm{mM}$ L-DOPA with $0.3 \%$ hydrogen peroxide for the peroxidase assay. The plates were covered and incubated for 1.5 hours at $20^{\circ} \mathrm{C}$. Absorbance was read on a microplate spectrophotometer (Bio-Tek $\mu$ Quant microplate reader) with a $520 \mathrm{~nm}$ filter. Actual oxidative activity is the sum of phenol oxidase and peroxidase.

Nematode indicators. Nematode communities were extracted from compost using a mist extraction method and collected in a water-filled tube. Total number of nematodes were counted per sample and a $10 \%$ subsample was identified to family (Bongers 1987) and placed into trophic group (Yeates et al. 1993). A maturity index (MI) was calculated as a weighted mean (Bongers 1990). The ratio of fungivorous to bacterivorous nematode abundance was calculated as $\mathrm{F} / \mathrm{B}=$ fungivores/(fungivores + bacterivores).

\section{Statistical analyses}

Analysis of covariance was employed to analyze effects of compost process, maturity, and feedstock as independent variables on disease severity, ecoenzyme activity, and nematode 
ecology as dependent variables. The source facility of the compost was held as a random effect, and the covariables were microbial biomass carbon, respiration, $\mathrm{C}: \mathrm{N}, \mathrm{pH}, \mathrm{EC}$, and the compost extract plate assay. Tukey post-hoc comparisons were performed to compare among levels of independent variables. Multiple stepwise regression (forward selection) was performed with disease severity as the dependent variable. Independent variables were microbial carbon, respiration, $\mathrm{C}: \mathrm{N}, \mathrm{pH}, \mathrm{EC}$, compost extract plate assay, ecoenzyme activity, and nematode indices. Normality, analysis of covariance, and multiple stepwise regression were performed using the UNIVARIATE, MIXED and REG procedures, respectively, in SAS version 9.3. All variables were assessed for normality using the UNIVARIATE procedure. Only C:N and EC required transformation, each with a natural log transformation $(x+1)$. All statistically analyses were performed with transformed variables.

\section{Process, maturity and feedstock}

\section{RESULTS}

Disease severity was affected consistently by compost process and maturity (Figure 1, Table 3). Vermicompost and anaerobic digestate were more suppressive than windrow or ASP composts. Mature composts were more suppressive than immature composts. Feedstock containing dairy manure and/or hardwood bark tended to have significant disease suppression. In contrast, poultry manure based compost promoted disease. Growth of $R$. solani mycelium on compost extract was affected by process and feedstock but not maturity. Growth was reduced most by vermicompost and windrow processes and feedstock containing hardwood bark (Figure 2).

Effects of compost process, maturity and feedstock depended on ecoenzyme type. For example, NAG activity was greater in vermicompost than ASP and windrow. In contrast, PP and LAP activity was greater in windrow than ASP or vermicompost (Figure 3A). LAP activity was greater in mature than immature compost (Figure 3B), but activity of the other ecoenzymes was similar among maturity classes. PP and BG activity were greater in dairy manure than poultry, food waste or hardwood bark feedstocks (Figure 3C). Effects on oxidative activity was similar across process, maturity and feedstock.

Nematode indices differentiated levels of compost maturity and feedstock but not process (Figure 4). Specifically, F/B were greater in immature than mature composts $(P<0.005)$. Successional maturity was greater in hardwood bark than other feedstocks (Figure 4C). Relatively few fungivorous nematodes in three families (Aphelenchidae, Paraphelenchidae, Qudsianematidae) were present.

\section{Best predictors of disease suppression}

Disease severity was better predicted by the indicators not currently used by compost industry. Nematode MI, compost extract plate assay, and three ecoenzymes (phosphatase, BG and NAG) were the best predictors of disease suppressiveness (Table 4). In contrast, microbial carbon, $\mathrm{CO}_{2}$ respiration, $\mathrm{C}: \mathrm{N}, \mathrm{EC}, \mathrm{pH}$, nematode $\mathrm{F} / \mathrm{B}$, oxidative and leucine amino peptidase ecoenzymes were less satisfactory predictors of disease suppression.

\section{DISCUSSION}


This study was designed to identify a biological indicator(s) that could be used to routinely test compost for general or specific disease suppression properties. A mature vermicompost containing hardwood bark as a carbon source has the greatest potential for suppressing Rhizoctonia solani on radish. This result is sufficiently robust to span a representative sample of commercial products that have all meet thermophilic requirements to kill plant pathogens and weed seeds established by the National Organic Standards Board (www.ams.usda.gov/nop). Achievement of these temperatures requires feedstock blends that average 25:1 to 30:1 C:N ratio, have $55-60 \%$ moisture, and a plentiful supply of oxygen, whether it be by turning piles or forcing air through a pile.

\section{Process}

Regardless of feedstock mixture, this study supports other reports that thermophilic compost cured by vermicompost holds unique properties that foster more disease suppression than thermophilic composts cured by windrow or ASP. This has been shown not only for $R$. solani on radish (this study), but also Pythium aphanidermatum on cucumber (Jack et al. 2011; Jack 2012). Vermicompost has substantially different bacterial and fungal communities when compared to those from a common recipe produced by windrow, and also has much greater bacterial diversity, which may support its ability to outcompete pathogens (Neher et al. 2013). Earthworms promote the growth of bacteria including Bacteriodetes, Verrucomicrobia, Firmicutes, and Proteobacteria. There is also a trend for greater diversity of fungi in vermicompost and a relatively high abundance of fungi including Mortierella and Arthrobotrys (Neher et al. 2013). Application rates of < 5\% promoted disease suppression and rates exceeding $25 \%$ promoted phytotoxicity. Vermicompost typically contains much nitrate but may have high EC that can result in germination problems and phytotoxicity in some plants (Pathma and Sakthivel 2012). In other cases, the benefits of vermicompost do not correlate with dosage, but affect plant growth indirectly possibly through plant microbial interactions (Zaller 2007, Jack et al. 2011). These organisms may manipulate plant growth by excreting exogenous microbial plant hormone analogs (Robert-Seilaniantz et al. 2011; Pangesti et al. 2013), and may further be responsible for disease suppression.

\section{Maturity}

Specific communities of saprophytic fungi and bacteria can be found at different successional stages of composting (Neher et al. 2013). Maturity or curing time is an indicator of substrate composition and microbial community, not necessarily stability (Oviedo-Ocana et al. 2015). This study suggests that mature composts offer more disease suppression of $R$. solani than immature composts. This finding affirms other studies of Rhizoctonia diseases that report immature compost was conducive to disease development (Kuter et al. 1988; Hoitink et al. 1996). Compost that had been cured for five months showed better suppression than compost that had been cured for three or seven months (Tuitert et al. 1998). Mature composts with high chitin content contain abundant rhizosphere bacteria producing chitin and $\beta$-glucosinase that damage cell walls of fungal pathogens (Kavroulakis et al. 2010). Chitin amendments increase populations of Actinobacteria and $\boldsymbol{\gamma}$-Proteobacteria (Postma and Schilder 2015).

\section{Feedstock}


Use of hardwood bark compost suppressed hyphal growth of $R$. solani in the compost extract plate assay. Pathogens, such as $R$. solani, are favored in early stages of composting when concentrations of labile carbon are high (Chung et al. 1988). Once labile carbons are depleted, the efficacy of biological control fungi such as Trichoderma hamatum increases (Chung et al. 1988). T. hamatum hyperparasitizes mycelium of $R$. solani by producing cellulases, glucanases, and chitinases. Contrary to other studies, we did not find Trichoderma (Hypocreaceae) in our composts. However, other fungi in the Hypocreales were common at the end of the curing process, e.g., Acremonium (Neher et al. 2013). This supports the hypothesis that specific biocontrol organisms may not be as important as microbial consortia (Postma and Shilder 2015).

\section{Best Predictors of Disease suppression}

Similar to the conclusions and recommendations of Alfano et al. (2011), the plate competition assay is a quick preliminary assessment of disease suppression, but not reliable as a standalone assay. Confirmation by a greenhouse bioassay makes a more robust assessment. There is more complexity in the soil and compost ecosystem than could be mimicked entirely by a laboratory assay. Microbial communities play a significant role, as does the presence of a plant. Two other in situ measures that contributed to predicting disease severity related to ecoenzyme activity and nematode communities in the soil food web.

Among all of the indicators assessed, ecoenzymes were the best potential indicator of disease suppressive compost. Ecoenzymes integrate information about environmental substrate composition, microbial nutrient acquisition, and microbial community metabolic function (Allison et al. 2007). Ecoenzymes capture the current state of microbial community metabolism, and serve as indicators of which substrates and decomposition functions are most abundant, or which nutrients are most limited. The most studied case of ecoenzymatic stoichiometry is the generally inverse relationship between phosphatase activity and environmental $P$ availability (Chróst and Overbeck 1987).

Greater values of either nematode index (F/B, MI) reflect less disturbance or a later stage of succession (Neher 2010). In this study, F/B was responsive to compost maturity and MI affected by feedstock, but not vice versa. MI predicted disease severity of $R$. solani on radish seedlings but not F/B. Fungivorous nematodes were expected to be abundant in relatively mature composts (Steel et al. 2010, Termorshuizen et al. 2006), but few were found in any compost samples of this study. Although Aphelenchideae were present, they were not associated with suppressing Rhizocotonia damping off on radish as reported on cauliflower (Lagerlöf et al. 2011). MI values require family identification rather than simply trophic group, perhaps increasing its sensitivity as an indicator of disease suppression. This supports the hypothesis that suppressive ability depends on a specific ecological environment (Termorshuizen et al. 2006; Hadar and Papadopoulou 2012).

Oxidative activity, or lignin degradation activity, was expected to be significant in disease suppression, representing an ecological condition favoring biological control agents over a pathogen. However, we were unable to identify significant differences among process, maturity, or feedstock. These results contrast another study suggesting the incorporation of lignin into soil reduced the viability of $R$. solani sclerotia (van Beneden et al. 2010). 


\section{CONCLUSIONS}

Our study provides empirical data to support adoption of a compost extract competition assay, nematode $\mathrm{Ml}$, and ecoenzymes active on cellulose and chitin as indicators of disease suppression by $R$. solani. General measures of microbial respiration may measure compost stability but not necessarily disease suppression of a facultative saprophyte like $R$. solani (Scheuerell et al. 2005; Bonanomi et al. 2010). These indicators are quicker than plant bioassays and could be adopted as tools to certify commercial products.

\section{REFERENCES}

Alfano, G., G. Lustrato, G. Lima, D. Vitullo, and G. Ranalli. 2011. “Characterization of Composted Olive Mill Wastes to Predict Potential Plant Disease Suppressiveness." Biological Control 3:199-207.

Allison, S.D., T. Gartner, K. Holland, M. Weintraub, and R.L. Sinsabaugh. 2007. "Soil Enzymes: Linking Proteomics and Ecological Process" in Manual of Environmental Microbiology. (Washington, DC: American Society of Microbiology Press), 704-11.

Allison, S. 2008. "Chloroform Fumigation Direct Extraction (CFDE) Protocol for Microbial Biomass Carbon and Nitrogen." University of California, Irvine, accessed October 7, 2014, http://allison.bio.uci.edu/protocols/microbiabiomasscn.pdf.

Bonanomi, G., V. Antignani, C. Pane, and E. Scala. 2007. "Suppression of Soilborne Fungal Diseases with Organic Amendments." Journal of Plant Pathology 89:311-24.

Bongers, T. 1987. "De Nematoden van Nederland." Schoorl, Netherlands: Pirola.

Bongers, T. 1990. "The Maturity Index: An Ecological Measure of Environmental Disturbance Based on Nematode Species Composition." Oecologia 83:14-19.

Bonanomi, G., V. Antignani, M. Capodilupo, and F. Scala. 2010. "Identifying the Characteristics of Organic Soil Amendments That Suppress Soilborne Plant Diseases." Soil Biology and Biochemistry 42:136-44.

Brinton, W.F.J., E. Evans, M.L. Droffner, and R.B. Brinton. 1995. "Standardized Test for Evaluation of Compost Self-Heating." Biocycle 36:64-68.

Chan, S., B. Caldwell, B. Rickard, and C. Mohler. 2011. "Economic Performance of Organic Cropping Systems for Vegetables in the Northeast". Journal of Agribusiness 29:59-82.

Chung, Y.R., H.A.J. Hoitink, and P.E. Lipps. 1988. "Interactions between Organic-Matter Decomposition Level and Soilborne Disease Severity." Agriculture Ecosystems and Environment 24:183-93.

Chung, Y., and H.A.J. Hoitink. 1990. "Interactions between Thermophilic Fungi and Trichoderma hamatum in Suppression of Rhizoctonia Damping-Off in a Bark Compost-Amended Container Medium." Disease Control and Pest Management 80:73-77.

Chróst, R.J., and J. Overbeck. 1987. "Kinetics of Alkaline Phosphatase and Phosphorus Availability for Phytoplankton and Bacterioplankton in Lake Plussee. Microbiology Ecology 13:229-48.

Coleman, D.C., D.A. Crossley, Jr., and P.F. Hendrix. 2004. Fundamentals of Soil Ecology, 2nd Ed. New York: Elsevier Academic Press.

Ersahin, Y.S., K. Haktanir, and Y. Yanar. 2009. "Vermicompost Suppresses Rhizoctonia solani Kühn in Cucumber Seedlings." Journal of Plant Disease Protection 116:182-88. 
Fang, L. 2015. "Biological Indicators of Compost-Mediated Disease Suppression Against the Soilborne Plant Pathogen Rhizoctonia solani." (MS thesis, University of Vermont).

Gómez, R.B., F. V. Lima, and A.S. Ferrer 2006. "The Use of Respiration Indices in the Composting Process: A Review." Waste Management Research 24:37-47.

González García, V., M.A. Portal Onco, and V. Rubio Susan. 2006. "Review. Biology and Systematics of the Form Genus Rhizoctonia." Spanish Journal of Agricultural Research 4:5579.

Goyal, S., S.K. Dhull, and K.K. Kapoor. 2005. "Chemical and Biological Changes During Composting of Different Organic Wastes and Assessment of Compost Maturity. Bioresource Technology 96:1584-91.

Hadar, Y. and K. Papadopoulou. 2012. "Suppressive Composts: Microbial Ecology Links Between Abiotic Environments and Healthy Plants." Annual Review of Phytopathology 50:133-53.

Hoitink, H.A.J., and M.J. Boehm. 1999. "Biocontrol Within the Context of Soil Microbial Communities: A Substrate-Dependent Phenomenon." Annual Review of Phytopathology 37:427-46.

Horsfall, J.G., and E.B. Cowling. 1978. "Pathometry: The Measurement of Plant Diseases." In Plant Disease: An Advanced Treatise. Vol. II: How Disease Develops in Populations, edited by John G. Horsfall and Ellis B. Cowling, 119-36. New York: Academic Press.

Jack, A. 2012. "Vermicompost Suppression of Pythium aphanidermatum Seedling Disease: Practical Applications and an Exploration of the Mechanisms of Disease Suppression." (PhD diss., Cornell University).

Jack, A.L.H., A. Rangarajan, S.W. Culman, T. Sooksa-Nguan, and J.E. Thies. 2011. "Choice of Organic Amendments in Tomato Transplants Has Lasting Effect on Bacterial Rhizosphere Communities and Crop Performance in the Field." Applied Soil Ecology 48:94-101.

Kavroulakis, N., S. Ntougias, M.I. Besi, P. Katsou, A. Damaskinou, C. Ehaliotis, G.I. Zervakis, K.K. Papadopoulou. 2010. "Antagonistic Bacteria of Composted Agro-Industrial Residues Exhibit Antibiosis Against Soil-Borne Fungal Plant Pathogens and Protection of Tomato Plants From Fusarium oxysporum f.sp. radicis-lycopersici." Plant and Soil 333:233-47.

Komilis, D.P., and I.S. Tziouvaras. 2009. "A Statistical Analysis to Assess the Maturity and Stability of Six Composts." Waste Management 29:1504-13.

Kuter, G.A., H.A.J. Hoitink, and W. Chen. 1988. "Effects of Municipal Sludge Compost Curing Time on Suppression of Pythium and Rhizoctonia Diseases of Ornamental Plants. Plant Disease 72:751-56.

Lagerlöf, J., V. Insunza, B. Lundegårdh, and B. Rämert. 2011. "Interaction Between a Fungal Plant Disease, Fungivorous Nematodes and Compost Suppressiveness." Acta Agriculturae Scandinavica: Section B, Soil and Plant Science 61:372-77.

Moorhead, D.L., Z.L. Rinkes, R.L. Sinsabaugh, and M.N. Weintraub. 2013. "Dynamic Relationships between Microbial Biomass, Respiration, Inorganic Nutrients, and Enzyme Activities: Informing Enzyme-Based Decomposition Models." Frontiers in Microbiology 4:112.

Neher, D.A. 2010. "Ecology of Plant and Free-Living Nematodes in Natural and Agricultural Soil." Annual Review of Phytopathology 48:371-94. 
Neher, D.A., T.R. Weicht, S.T. Bates, J.W. Leff, and N. Fierer. 2013. "Changes in Bacterial and Fungal Communities Across Compost Recipes, Preparation Methods, and Composting Times." PLOS One 8:e79512.

Oviedo-Ocanna, E.R., P. Torres-Lozada, L.F. Marmoloejo-Rebellon, L.V. Hoyos, S. Gonzales, R. Barrena, D. Komilis, and A. Sanchez. 2015. "Stability and Maturity of Biowaste Composts Derived by Small Municipalities: Correlation Among Physical, Chemical and Biological Indices." Waste Management 44:63-71.

Pane, C., R. Spaccini, A. Piccolo, F. Scala, and G. Bonanomi. 2011. "Compost Amendments Enhance Peat Suppressiveness to Pythium ultimum, Rhizoctonia solani, and Sclerotinia minor." Biological Control 56:115-24.

Pane, C., A. Piccolo, R. Spaccini, G. Celano, D. Villecco, and M. Zaccardelli. 2013. "Agricultural Waste-Based Composts Exhibiting Suppressivity to Diseases Caused by the Phytopathogenic Soil-Borne Fungi Rhizoctonia solani and Sclerotinia minor." Applied Soil Ecology 65:43-51.

Pathma, J. and N. Sakthivel. 2012. "Microbial Diversity of Vermicompost Bacteria That Exhibit Useful Agricultural Traits and Waste Management Potential." SpringerPlus 1:26.

Postma, J. and M.T. Schilder. 2015. "Enhancement of Soil Suppressiveness Against Rhizoctonia solani in Sugar Beet by Organic Amendments." Applied Soil Ecology 94:72-79.

Saiya-Cork, K.R., R.L. Sinsabaugh, and D.R. Zak. 2002. "The Effects of Long Term Nitrogen Deposition on Extracellular Enzyme Activity in an Acer saccharum Forest Soil." Soil Biology and Biochemistry 34:1309-15.

Santos, M., F. Diánez, M. González del Valle, and J.C. Tello. 2008. "Grape Marc Compost: Microbial Studies and Suppression of Soil-Borne Mycosis in Vegetable Seedlings." World Journal of Microbiology and Biotechnology 24:1493-505.

Scheuerell, S.L., D.M. Sullivan, and W.F. Mahafee. 2005. "Suppression of Seedling Damping-Off Caused by Pythium ultimum, P. irregulare, and Rhizoctonia solani in Container Media Amended with a Diverse Range of Pacific Northwest Compost Sources." Phytopathology 95:306-315.

Smith, J.L. and J.W. Doran. 1996. "Measurement and Use of pH and Electrical Conductivity for Soil Quality Analysis," In Methods for Assessing Soil Quality, edited by John W. Doran, and Alice J. Jones, 169-85. Madison, Wisconsin: Soil Science Society of America Special Publication 49.

Steel, H., E. de la Peña, P. Fonderie, K. Willekens, G. Borgonie, and W. Bert. 2010. "Nematode Succession during Composting and the Potential of the Nematode Community as an Indicator of Compost Maturity." Pedobiologia 53:181-190.

Strange, R.N., and P.R. Scott. 2005. "Plant Disease: A Threat to Global Food Security." Annual Review of Phytopathology 43:83-116.

Termorshuizen, A.J., E. van Rijn, D.J. van der Gaag, C. Alabouvette, Y. Chen, J. Logerlöf, A.A. Malandrakis, E.J. Paplomatas, B. Rämert, J. Ryckeboer, C. Steinberg, and S. Zmora-Nahum. 2006. "Suppressiveness of 18 composts Against 7 Pathosystems: Variability in pathogen Response." Soil Biology and Biochemistry 38:2461-77.

Thompson, W.H., P.B. Leege, P.D. Millner, M.E. Wilson. 2001. "Test Methods for the Examination of Composting and Compost," Holbrook, New York:United States Composting Council Research and Education Foundation. The Department of Agriculture. 
Tuitert, G., M. Szczech, and G.J. Bollen. 1998. "Suppression of Rhizoctonia solani in Potting Mixtures Amended with Compost Made from Organic Household Waste." Phytopathology 88:764-73.

USDA-ERS. 2016. "Overview- Vegetables and Pulses", accessed October 13, 2016, http://www.ers.usda.gov/topics/crops/vegetables-pulses.aspx.

Wichuk, K.M. and D. McCartney. 2010. "Compost Stability and Maturity Evaluation - A Literature Review." Canadian Journal of Civil Engineering 37:1505-23.

Yeates, G.W., T. Bongers, T., R.G.M. de Goede, D.W. Freckman, and S.S. Georgieva. 1993. "Feeding Habits in Soil Nematode Families and Genera - An Outline for Soil Ecologists." Journal of Nematology 25:315-31.

Zaller, J.G. 2007. "Vermicompost in Seedling Potting Media can Affect Germination, Biomass Allocation, Yields and Fruit Quality of Three Tomato Varieties." European Journal of Soil Biology 43:S332-36. 
TABLE 1. Recipe/Primary Feedstock, pile type, maturity level in factorial combinations with two stages of compost maturity and infestation by $R$. solani pathogen.

Recipe/Primary Feedstock Facility Pile Type Maturity

\begin{tabular}{llll}
\hline Hardwood Bark $^{\mathrm{a}}$ & Highfields Ctr for Composting & Windrow & Very Mature \\
Commercial Standard & Highfields Ctr for Composting & ASP/Windrow & Fresh $^{\mathrm{f}}$ \\
Commercial Standard & Highfields Ctr for Composting & ASP/Windrow & Mature $^{\mathrm{g}}$ \\
Commercial Standard & Highfields Ctr for Composting & Vermicompost & Mature \\
Cow Manure - silage & Worm Power & Vermicompost ${ }^{\text {WP }}$ & Mature \\
Commercial Standard & Vermont Compost & Windrow & Fresh \\
Commercial Standard & Vermont Compost & Windrow & Mature \\
Commercial Standard & Green Mountain Compost & ASP/Windrow & Fresh \\
Commercial Standard & Green Mountain Compost & ASP/Windrow & Mature \\
Commercial Standard & Grow Compost & Windrow & Fresh \\
Commercial Standard & Grow Compost & Windrow & Mature \\
On-Farm & Riverside Organic Farm & Windrow & Mature \\
Cow Manure/Silage & Green Mountain Power & Anaerobic Digestion & N/A \\
\hline
\end{tabular}

a: custom prepared with yellow birch as a carbon source mixed in a 5:5:3 ratio of manure/silage: hardwood bark: softwood shavings resulting in a C:N ratio of 34:1

b: $20 \%$ food residuals, $10-15 \% 2.4 \mathrm{~cm}$ woody materials (e.g., hardwood bark and mixed wood chips), $10 \%$ hay, up to $5 \%$ shredded paper, up to $2 \%$ dry sawdust or shavings, and $50-60 \%$ mixed livestock manures (e.g., horse, cow, heifer, calf) mixed with various bedding materials (e.g., straw and hay)

c: variety of materials, including food waste, manure, especially chicken manure, and wood materials, no biodegradable plastic products

${ }^{d}$ : a municipal compost facility taking in food and yard waste and some manure, as well as biodegradable plastic products

e: mixture of wood materials, food scraps, hay, manure, and yard waste, no biodegradable plastic products

f: fresh, but post-thermophilic

g: ready to sell

h: poultry manure and softwood cedar shavings

i: manure/silage fed to digester; remaining solids are separated and dehydrated and analyzed 
TABLE 2. Indicators of compost maturity or stability tested for their ability to predict disease suppression of Rhizoctonia solani.

\begin{tabular}{|c|c|c|c|}
\hline Assay & Function & Units & Reference \\
\hline $\begin{array}{l}\text { Chloroform } \\
\text { Fumigation Extraction }\end{array}$ & $\begin{array}{l}\text { microbial biomass } \\
\text { carbon }\left(\mathrm{C}_{\text {mic }}\right)\end{array}$ & $\begin{array}{l}\mu \mathrm{g} \text { C/g dry weight } \\
\text { compost }\end{array}$ & Allison 2008 \\
\hline $\begin{array}{l}\text { Sodium Hydroxide } \\
\text { Titration }\end{array}$ & $\begin{array}{l}\text { microbial activity } \\
\text { via } \mathrm{CO}_{2} \text { respiration }\end{array}$ & $\begin{array}{l}\mathrm{mg} \mathrm{CO} / \mathrm{hr} / \mathrm{g} \text { dry } \\
\text { weight compost }\end{array}$ & $\begin{array}{l}\text { Oviedo-Ocańa et al. } \\
2015\end{array}$ \\
\hline Solvita ${ }^{\mathrm{TM}}$ & $\begin{array}{l}\text { stability measured } \\
\text { by respiration and } \\
\mathrm{N} \text { mineralization } \\
\text { rate }\end{array}$ & 8-point color scale & $\begin{array}{l}\text { Solvita 2009; Brinton et } \\
\text { al. } 1995\end{array}$ \\
\hline CHN Analysis & limiting nutrient & ratio & Goyal et al. 2005 \\
\hline $\begin{array}{l}\mathrm{pH} \text { and electrical } \\
\text { conductivity (EC) }\end{array}$ & salt concentration & $\begin{array}{l}\text { EC measured in } \\
\mathrm{mS} / \mathrm{cm}\end{array}$ & Smith and Doran 1996 \\
\hline Ecoenzyme Analysis & $\begin{array}{l}\text { decomposition } \\
\text { activity; nutrient } \\
\text { availability }\end{array}$ & $\begin{array}{l}\mathrm{nmol} / \mathrm{h} / \mathrm{g} \text { dry weight } \\
\text { compost or } \mu \mathrm{mol} / \mathrm{h} / \mathrm{g} \\
\text { dry weight compost; } \\
\text { ecoenzymatic } \mathrm{C}: \mathrm{N}: \mathrm{P} \\
\text { acquisition }\end{array}$ & Saiya-Cork et al. 2002 \\
\hline $\begin{array}{l}\text { Plate competition } \\
\text { assay }\end{array}$ & $\begin{array}{l}\text { competition against } \\
\text { pathogen }\end{array}$ & $\begin{array}{l}\text { millimeters (mm) } \\
\text { mycelium/day }\end{array}$ & Alfano et al. 2011 \\
\hline Nematode Community & $\begin{array}{l}\text { nematode } \\
\text { ecological } \\
\text { successional index }\end{array}$ & $\begin{array}{l}\mathrm{MI} \\
\mathrm{F} / \mathrm{B}\end{array}$ & $\begin{array}{l}\text { Steel et al. 2010; } \\
\text { Neher } 2010\end{array}$ \\
\hline
\end{tabular}


TABLE 3. Analysis of covariance. Effects of facility as random effect, process, maturity, and feedstock on disease severity, compost extract plate assay, ecoenzymes, and nematode indices, with microbial biomass carbon $\left(\mathrm{C}_{\text {mic }}\right)$, respiration $(\mathrm{Rs}), \mathrm{pH}$, electrical conductivity, C:N ratio, and plate competition assay (Rhiz) as covariables. Degrees of freedom for Numerator (N) and Denominator $(D), F$-values $(F)$ and levels of significance $(P)$ are illustrated.

\begin{tabular}{|c|c|c|c|c|c|c|c|c|c|c|c|c|c|c|c|c|c|c|}
\hline \multirow{3}{*}{ Dependent variable $^{a}$} & \multicolumn{12}{|c|}{ Independent variables } & \multicolumn{6}{|c|}{ Covariables } \\
\hline & \multicolumn{4}{|c|}{ Process } & \multicolumn{4}{|c|}{ Maturity } & \multicolumn{4}{|c|}{ Feedstock } & \multirow{2}{*}{$\frac{C_{\text {mic }}}{P^{b}}$} & \multirow{2}{*}{$\begin{array}{c}\text { Rs } \\
P\end{array}$} & \multirow{2}{*}{$\frac{\mathrm{pH}}{P}$} & \multirow{2}{*}{$\frac{E C}{P}$} & \multirow{2}{*}{$\frac{C: N}{P}$} & \multirow{2}{*}{$\frac{\text { Rhiz }}{P}$} \\
\hline & $\boldsymbol{F}$ & $\boldsymbol{P}$ & $\mathbf{N}$ & D & $\boldsymbol{F}$ & $\boldsymbol{P}$ & $\mathbf{N}$ & D & $\boldsymbol{F}$ & $\boldsymbol{P}$ & $\mathbf{N}$ & D & & & & & & \\
\hline Disease Severity & 8.82 & 0.0003 & 3 & 28 & 4.59 & 0.0410 & 1 & 28 & 0.59 & 0.6740 & 4 & 28 & n.s. & $*$ & n.s. & n.s. & n.s. & n.s. \\
\hline Plate competition assay & 2.1 & 0.1217 & 3 & 29 & 0.02 & 0.8993 & 1 & 29 & 4.19 & 0.0085 & 4 & 29 & $*$ & n.s. & n.s. & n.s. & n.s. & - \\
\hline BG & 2.79 & 0.0606 & 3 & 26 & 0.14 & 0.7144 & 1 & 26 & 6.54 & 0.0009 & 4 & 26 & n.s. & $*$ & n.s. & n.s. & $* *$ & $*$ \\
\hline NAG & 453.6 & $<0.0001$ & 3 & 26 & 1.32 & 0.2620 & 1 & 26 & 1.21 & 0.3302 & 4 & 26 & n.s. & $*$ & n.s. & n.s. & $* * *$ & $* *$ \\
\hline OX & 1.12 & 0.3613 & 3 & 25 & 0.98 & 0.3314 & 1 & 25 & 1.34 & 0.2843 & 4 & 25 & n.s. & n.s. & $* * *$ & $* * *$ & n.s. & n.s. \\
\hline LAP & 42.54 & $<0.0001$ & 3 & 26 & 6.44 & 0.0175 & 1 & 26 & 2.45 & 0.0714 & 4 & 26 & n.s. & n.s. & n.s. & n.s. & n.s. & n.s. \\
\hline PP & 18.98 & $<0.0001$ & 3 & 26 & 0.17 & 0.6880 & 1 & 26 & 8.91 & 0.0001 & 4 & 26 & n.s. & $* * *$ & n.s. & n.s. & $* *$ & $* *$ \\
\hline ESI & 0.64 & 0.5370 & 2 & 20 & 2.54 & 0.1270 & 1 & 20 & 12.19 & $<0.0001$ & 4 & 20 & n.s. & n.s. & $*$ & n.s. & $* * *$ & $* * *$ \\
\hline $\mathrm{F} / \mathrm{B}$ & 1.67 & 0.2130 & 2 & 20 & 10.0 & 0.0050 & 1 & 20 & 2.22 & 0.1031 & 4 & 20 & $* *$ & $* *$ & $*$ & n.s. & $* *$ & n.s. \\
\hline
\end{tabular}

a: PP: phosphatase, BG: $\beta$-glucosidase (cellulose), LAP: L-leucine aminopeptidase, NAG: $\beta$-1,4-N-acetylglucosaminidase (chitinase), OX: actual oxidative activity = peroxidase + phenol oxidase, ESI: ecological succession of nematode index, F/B: fungivorous nematodes / (fungivorous + bacterivorous nematodes)

b: n.s.: $P>0.05, *$ : $P \leq 0.05, * *: P \leq 0.01, * * *, P \leq 0.001,--$ not included 
TABLE 4. Multiple stepwise regression $\left(R^{2}=0.6861\right)$ to identify best predicators of disease severity of Rhizoctonia solani on radish seedlings.

\begin{tabular}{|l|c|c|c|c|}
\hline \multicolumn{1}{|c|}{ Variable } & $\begin{array}{c}\text { Parameter } \\
\text { Estimate }\end{array}$ & $\begin{array}{c}\text { Partial R- } \\
\text { square }\end{array}$ & F-value & $\boldsymbol{P}$-value \\
\hline Intercept & 0.47874 & & 33.62 & $<0.0001$ \\
\hline Ecological successional index (ESI) & -0.31887 & 0.1741 & 24.97 & $<0.0001$ \\
\hline Plate competition assay & 0.37964 & 0.0358 & 14.78 & 0.0007 \\
\hline Phosphatase (PP) activity & 0.00918 & 0.0493 & 14.68 & 0.0007 \\
\hline$\beta$-glucosidase (BG) activity & 0.06435 & 0.0439 & 7.95 & 0.0089 \\
\hline$\beta$-1,4-N-acetylglucosaminidase (NAG) & -0.13379 & 0.0808 & 21.3 & $<0.0001$ \\
\hline activity & & & & \\
\hline
\end{tabular}


FIGURE LEGENDS
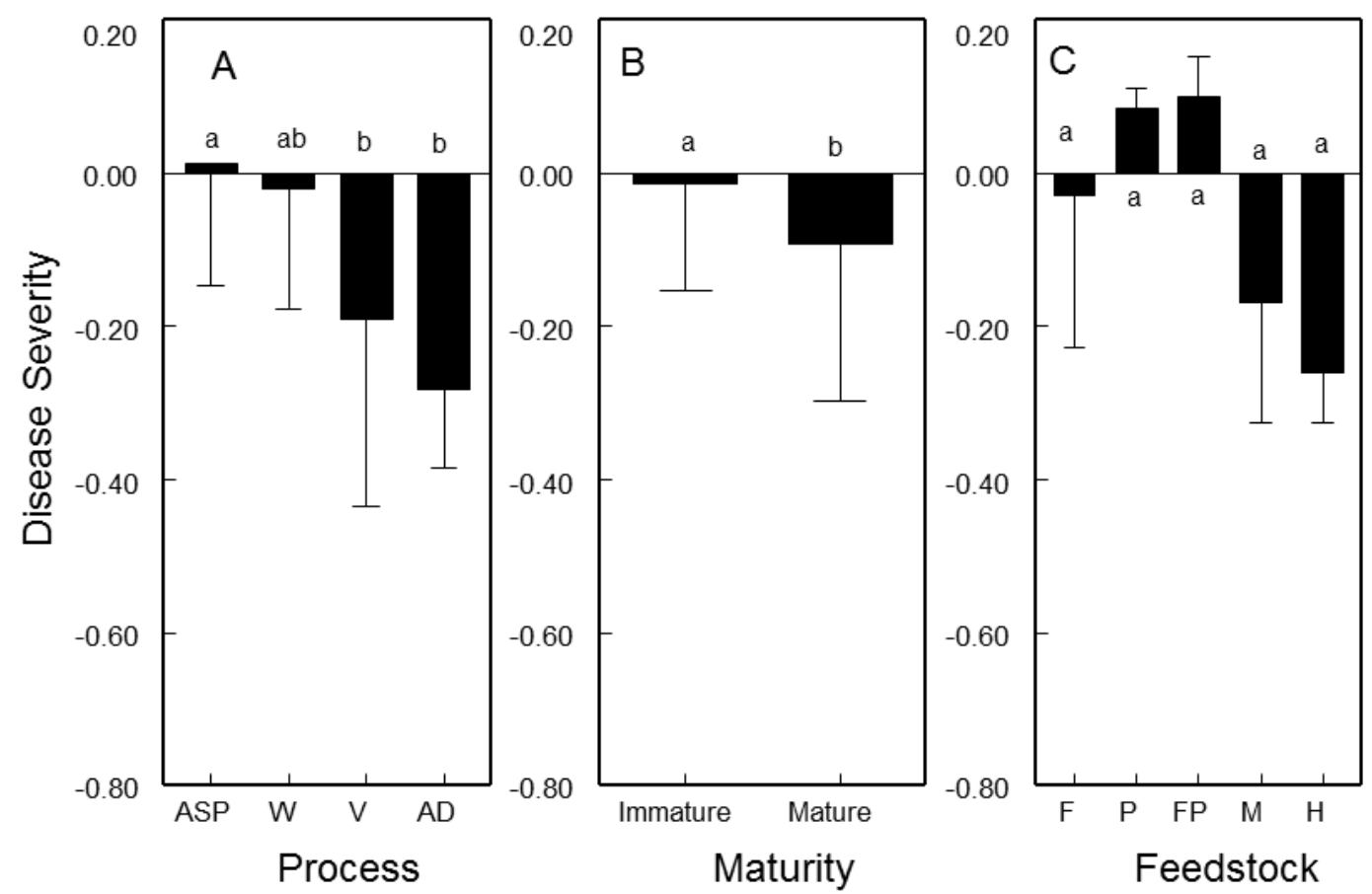

FIGURE 1. Disease severity affected by compost $A)$ process $(F=8.82, P=0.0003, A S P$ : aerated static pile, $W=$ windrow, $V=$ vermicompost, $A D=$ Anaerobic Digestate; $B)$ maturity $(F=4.59, P=$ 0.041, M=Mature; I=Immature); and C) feedstock ( $F=0.59,0.674, F=F o o d$ Waste, P=Poultry Manure, $\mathrm{M}=$ Dairy Manure, $\mathrm{FP}=$ Food Waste and Poultry Manure, $\mathrm{H}=\mathrm{Hardwood}$ Bark). Both controls and treatment comparisons were inoculated with virulent Rhizoctonia solani. Illustrated are means \pm 1 standard error of percent change from non-compost control. 

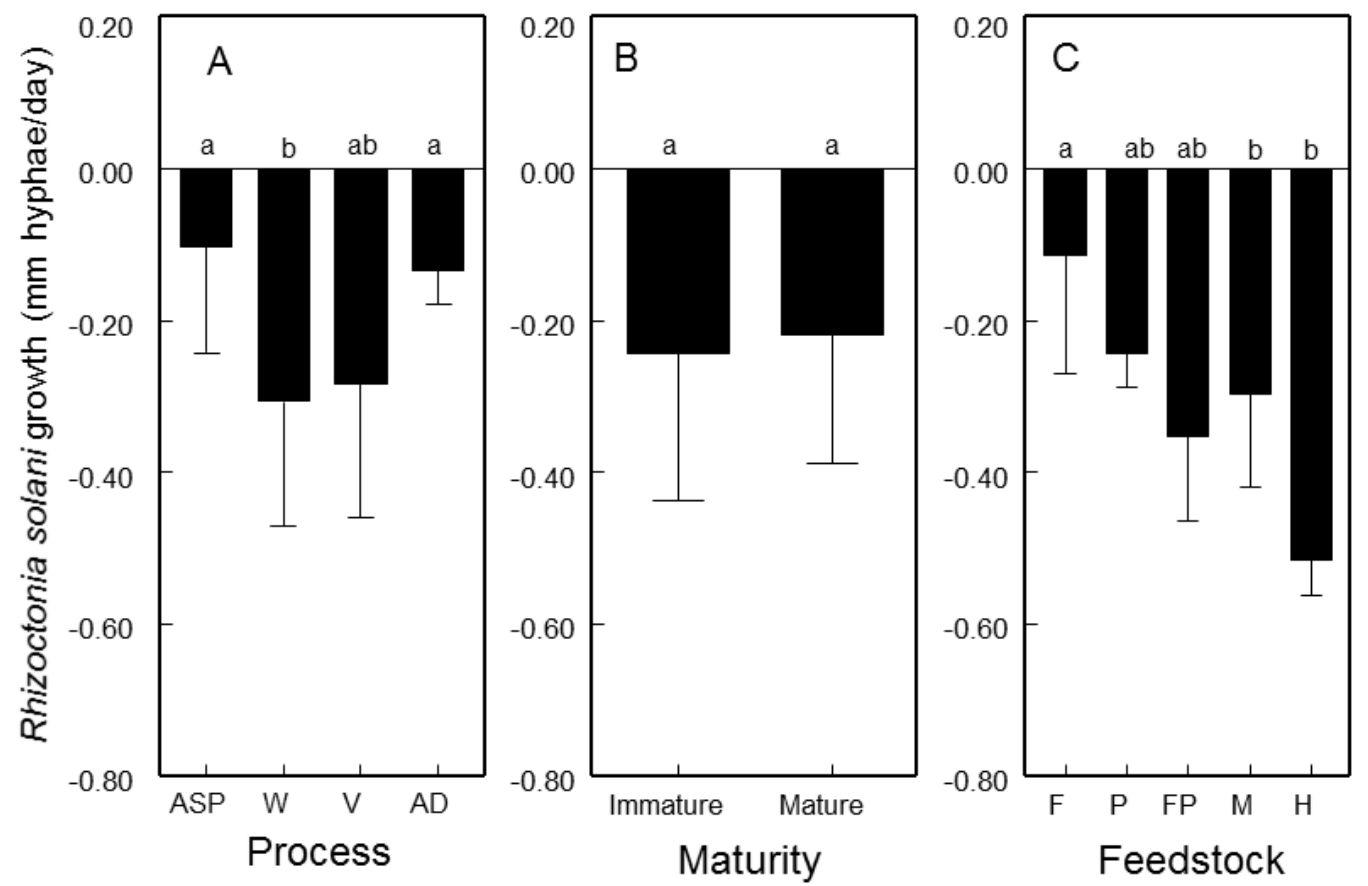

FIGURE 2. Plate competition assay measuring hyphal growth of Rhizoctonia solani on compost water extract agar affected by compost $A)$ process $(F=2.1, P=0.1217$, ASP: aerated static pile, $\mathrm{W}=$ windrow, $\mathrm{V}=$ vermicompost, $\mathrm{AD}=\mathrm{Anaerobic}$ Digestate; $\mathrm{B})$ maturity $(F=0.02, P=0.8993$, $\mathrm{M}=$ Mature; I=Immature); and $\mathrm{C}$ ) feedstock ( $F=4.19, P=0.0085, \mathrm{~F}=$ Food Waste, $\mathrm{P}=$ Poultry Manure, $\mathrm{FP}=$ Food Waste and Poultry Manure, $\mathrm{M}=$ Dairy Manure, $\mathrm{H}=\mathrm{Hardwood}$ Bark). Illustrated are means \pm 1 standard error of the change from non-compost control. Both controls and treatment comparisons were inoculated with virulent Rhizoctonia solani. 

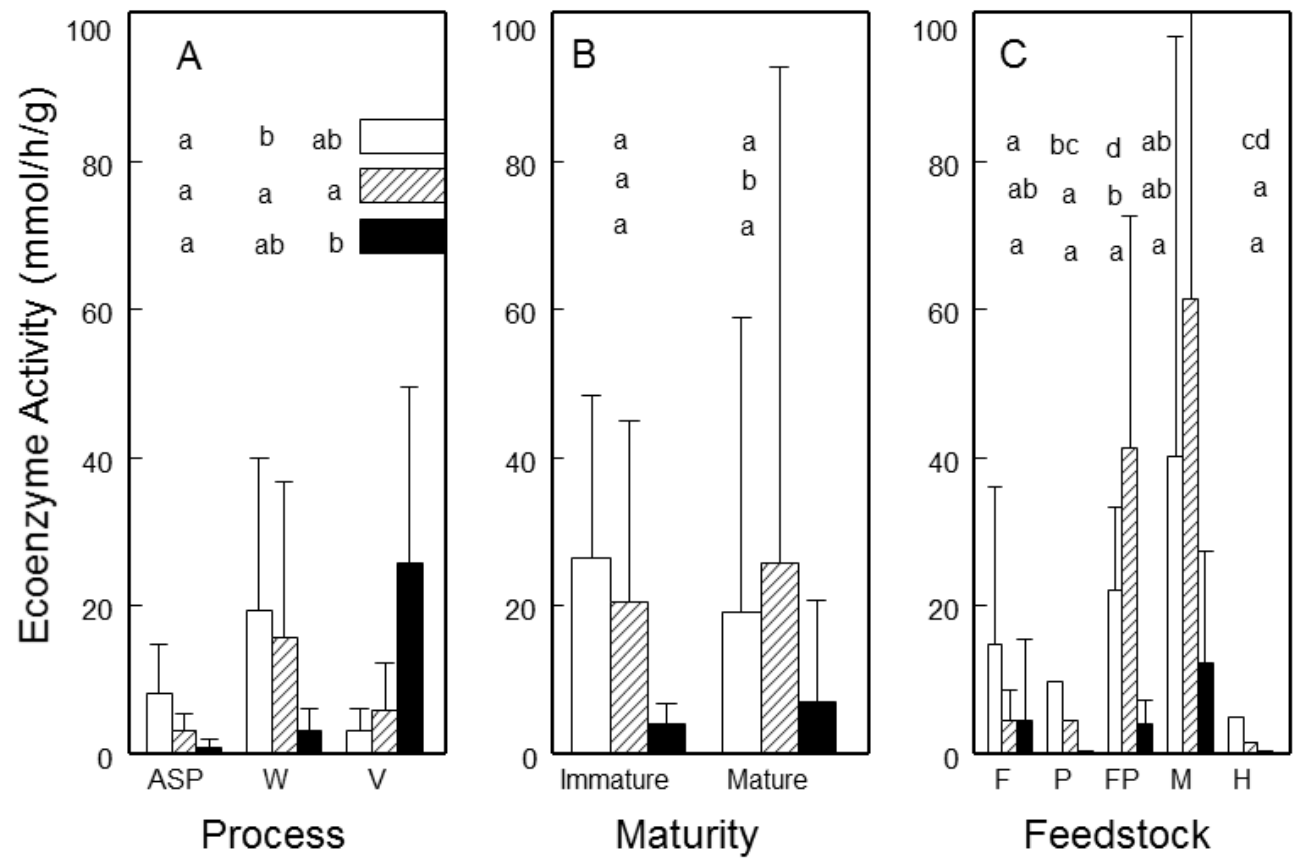

FIGURE 3. Ecoenzyme activity by A) process (ASP: aerated static pile, $W=$ windrow, $\mathrm{V}=$ vermicompost); $\mathrm{B}$ ) maturity ( $\mathrm{M}=$ Mature; I=Immature); C) feedstock (F=Food Waste, $\mathrm{P}=$ Poultry Manure, $\mathrm{FP}=$ Food Waste and Poultry Manure, $\mathrm{M}=$ Dairy Manure, $\mathrm{H}=\mathrm{Hardwood}$ Bark). Fill patterns represent ecoenzyme activities where white= Phosphatase; slash = L- leucine aminopeptidase; and black: $\beta-1,4)-\mathrm{N}$-acetylglucosaminidase (chitinase). Illustrated are means \pm 1 standard error of percent change from non-compost control. Both controls and treatment comparisons were inoculated with virulent Rhizoctonia solani. Post-hoc mean comparisons are represented by contrasting letters $(P<0.05)$ to the left of the fill pattern key within the first panel. 

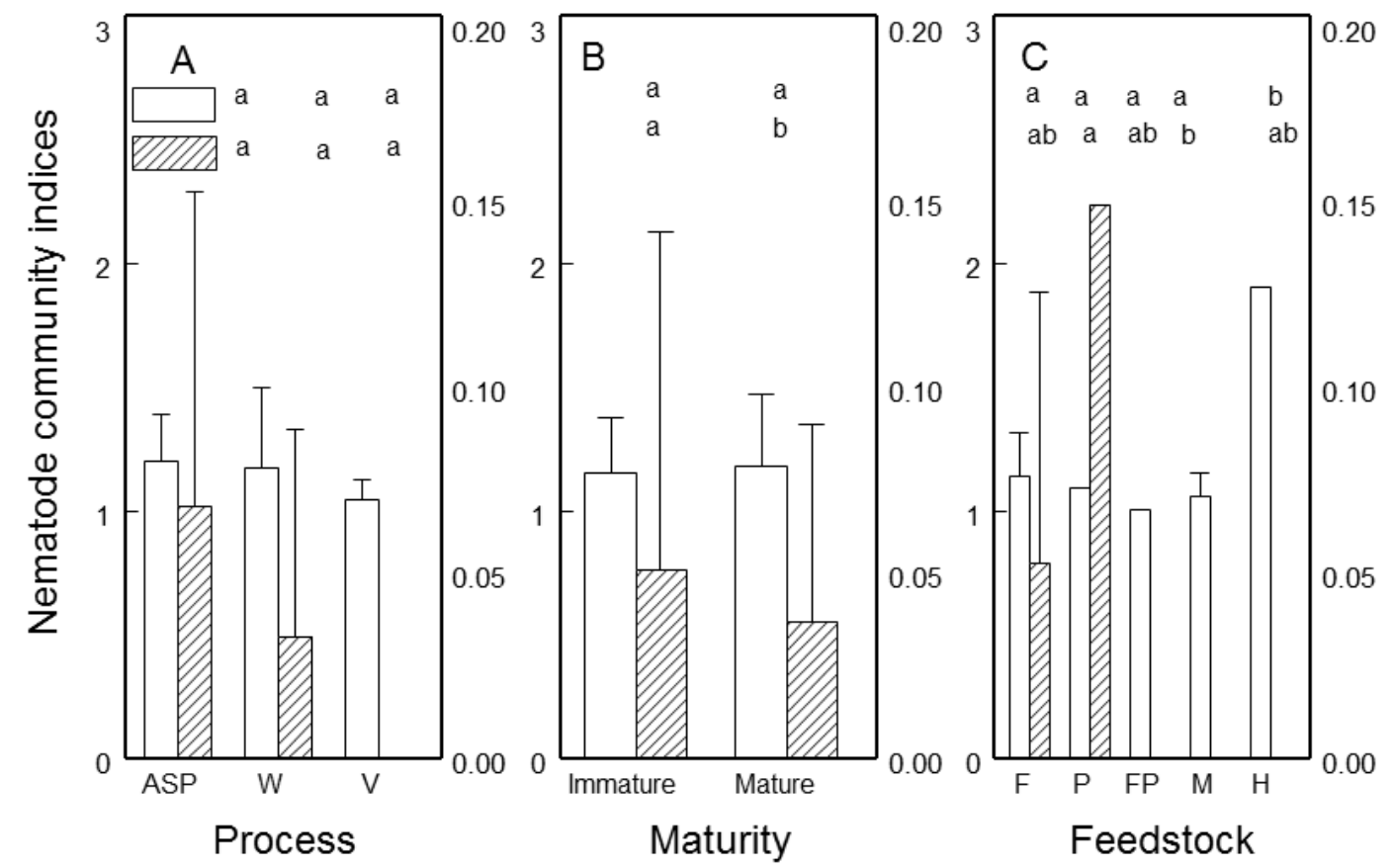

FIGURE 4. Nematode indices affected by compost A) process (ASP: aerated static pile, $\mathrm{W}=$ windrow, $\mathrm{V}=$ =vermicompost); $\mathrm{B}$ ) maturity ( $\mathrm{M}=$ Mature; $\mathrm{I}=\mathrm{Immature}$ ); $\mathrm{C}$ ) feedstock ( $\mathrm{F=Food}$ Waste, $\mathrm{P}=$ Poultry Manure, FP=Food Waste and Poultry Manure, $\mathrm{M}=$ Dairy Manure, $\mathrm{H}=\mathrm{Hardwood}$ Bark). Fill patterns represent community indices where open =maturity index (left $y$-axis), slash $=$ fungivorous to bacterivorous (right $y$-axis) nematode abundance. Illustrated are means \pm 1 standard error. Post-hoc mean comparisons are represented by contrasting letters $(P<0.05)$ to the right of the fill pattern key within the first panel. 